czeniu z kolonializmem. Trend ten jest coraz bardziej widoczny od schyłku lat 80 . XX wieku (np. kontrowersyjna wystawa Magiciens de la Terre (Paryż) z 1989 r. czy wystawy z cyklu Documenta, których kuratorami byli nie-Europejczycy (np. Okwui Enwezor). Okres wieku XXI jest zdominowany przez trend postcolonialny w sztuce (uznani artyści o tym profilu to: Fred Wilson (ur. 1954), Sonia Boyce (ur. 1962), Kara Walker (ur. 1969), Hew Locke (ur. 1959), Yinka Shonibare (ur. 1962), Kader Attia (ur. 1970)).

Słowa kluczowe: postkolonializm, podbój kolonialny, dyskurs, sztuka, Afryka, kolekcje

Aneta Pawłowska - PhD after habilitation, Faculty of Philosophy and History, Institute of History of Art, University of Łódź. She specializes in South African art and culture. Her research interests include: contemporary art, 20th century gender art and history and theory of collections. Her current research focuses on Audio description. Selected publications Sztuka $i$ kultura Afryki Potudniowej. W poszukiwaniu tożsamości artystycznej na tle przeksztatceń historycznych [Art and Culture of South Africa. In search of artistic identity of South Africa, as influenced by historical transformations], Łódź: Wydawnictwo Uniwersytetu Łódzkiego 2013; Studia o sztuce polskiej, Łódź: Wydawnictwo Uniwersytetu Łódzkiego 2017; Andrzej Jocz (1941-2019) ocalić od zapomnienia, Łódź: Wydawnictwo Uniwersytetu Łódzkiego 2021. 


\section{Piotr Gryglewski}

○ https://orcid.org/0000-0002-2712-2855

Institute of Art History, University of Łódź

piotrgryglewski@uni.lodz.pl.

\section{Denys Chernyshev}

(i) https://orcid.org/0000-0002-1946-9242

Kyiv National University of Construction and Architecture denis01011978@ukr.net

Oleksandr Kashchenko

๑ https://orcid.org/0000-0001-8570-264X

Kyiv National University of Construction and Architecture kashchenko.ov@knuba.edu.ua

\section{Alexander Shilo}

- $h$ ttps://orcid.org/0000-0002-8711-7521

Kharkiv National University of Civil Engineering and Architecture

alexandershilo55@gmail.com

\section{Yulia Ivashko}

- https://orcid.org/0000-0003-4525-9182

Kyiv National University of Construction and Architecture yulia-ivashko@ukr.net

\section{Andrii Dmytrenko}

(i) https://orcid.org/0000-0003-4757-5218

National University "Yuri Kondratyuk Poltava Polytechnic" metr5555@ukr.net

\section{Oleksandr Ivashko}

- https://orcid.org/0000-0002-9194-2153

Kyiv National University of Construction and Architecture ghok2233@gmail.com 


\title{
BETWEEN PRACTICE AND THEORY. COMMENTS ON THE SPECIFICITY OF ART HISTORY AND ART EDUCATION IN POLAND AND UKRAINE
}

\begin{abstract}
Changes taking place in the area of artistic practice happen in parallel with transformations in the social area. Artistic and architectural activity coexists with theoretical reflection in the field of art. Changes of this kind also translate into assumptions that guide research in the area of art history. Contemporary art is characterized by dynamic changes and re-evaluations, in which practice and theory are intertwined. The nature of these phenomena is also a challenge on the level of academic education dealing with the subject of art, architecture and art history. The specificity of the analyzed phenomena makes it necessary to combine theoretical knowledge with broadly understood practice in this process. The aesthetic premises of contemporary art are widely used in the process of artistic education. An example of this can be activities undertaken by the Kiev National University of Construction and Architecture (KNUCA). Successive lecturers at this university have consistently combined theory with creative practice in the educational process. These premises have found application in architectural design that uses plastic elements. The ties between theory and practice are also inherently inscribed in the history of the history of art department at the University of Lodz. It was largely influenced by the specificity of Łódź as an artistic center in which, very early, before World War II, there was an interest in modern art at the level of theory, practice and museology. This attitude was also close to the academic activity of prof. G. Sztabiński who successfully combined in-depth aesthetic and theoretical reflections with the experiences of an artistic practitioner.
\end{abstract}

Keywords: art theory, artistic education, teaching methodology, history of art, Łódź, Kiev

\section{Introduction}

The progressive development of humankind is accompanied by an inseparable connection of the material and spiritual spheres, an organic combination of utilitarian and artistic-aesthetic products of human activity.

The evolution of art, architecture and design is characterized by a synthesis of perfect form, construction and function, as well as figurative, compositional, artistic and aesthetic expression. Plastic arts - graphics, painting, sculpture, arts and crafts, monumental art are an integral part of the means of harmonizing the architectural environment. In addition, the possession of artistic means is a necessary basis for architectural creativity.

The psychology of creativity testifies to the effectiveness of a concentrated definition of an idea in the form of a figurative-logical imagination materialized in a graphic model - a drawing, a sketch. The best works of outstanding architects of the past and present, as a rule, began with quick sketches which captured the generalized main idea of the future architectural object. The sketches of Le Corbusier, Oscar Niemeyer, Santiago Calatrava, Norman 
Foster, Renzo Piano, Zaha Hadid, Frank Ghery and other outstanding architects became classic. Such sketches reveal the sensory-emotional state of the creator, which organically combines social experience and individuality. The artistic flair and talent of the architect are realized in a dual way - at the moment of the generalizing initial solution and in the process of creating a harmonious architectural environment with the use of art objects.

The artistic component in the creative process of an architect or designer has the value of the cognitive method, an analysis of the object, a situation, a reflection of the virtual image, its materialization and, as a consequence, the formation of a sensory, visual aesthetic field.

The issue of art and art history education - classical and modern - was of interest to many researchers. In particular, Grzegorz Sztabiński stressed that the traditional principles of artists have changed and the arts started to include phenomena that had not been previously considered, but he believed that the now common expression "the end of art" does not really mean the end of artistic creativity, but rather its unlimited and comprehensive development. ${ }^{1}$ According to Grzegorz Sztabiński, the modern meaning of the term art has acquired the character of integration, which was accompanied by various cultural phenomena. An important feature of contemporary art has been the interpretation of art as a performance, which Paulina Sztabińska-Kałowska has emphasized in her articles. ${ }^{2}$ This aspect must also be taken into account in the training of future artists, as the traditional educational system no longer fully meets the needs of today. That is why "Synthesis of Arts" is an important subject in the training of future artists, where students are introduced not only to traditional but also to modern arts, such as muralism and street art.

\section{Materials and methods}

The article uses traditional scientific methods - analytical and comparative analysis. This allows us to analyze the specifics of the training of artists at universities in accordance with the artistic needs of today. Based on the analy-

1 G. Sztabiński (2019) Why Do We Need the Term "Art”? "Art Inquiry. References sur les arts", vol. XXI (XXX), pp. 19-35.

2 P. Sztabińska (2014) Contemporary artist and the notion of center and periphery. "Art Inquiry. Recherches sur les arts" vol. XVI, pp. 45-56; P. Sztabińska (2016) Performance art, performativity and the issue of neomodernism. "Art Inquiry. Recherches sur les arts" vol. XVIII (XXVII), pp. 161-176; P. Sztabińska (2017) Digital performance and avant-garde artistic distinctions. "Art Inquiry. Recherches sur les arts" vol. XIX (XXVIII), pp. 257-272; P. Sztabińska-Kałowska (2018) Performance and Participatory Art. "Art Inquiry. Recherches sur lest arts" vol. XX (XXIX), pp. 185-201; P. Sztabińska-Kałowska (2019) How Does a Performance Affect the Understanding of 'Art'?, "Art Inquiry. Recherches sur les arts" vol. XXI (XXX), pp. 111-128. 
tical method, the authors have identified the features of art education of each scientific school, the works of prominent scientists and artists between the classical theory of teaching and the needs of today, which require adjustments, including changes in the training of artists. Based on the method of comparative analysis, the differences between the educational approaches of different schools and the effectiveness in solving certain specific educational problems were determined.

\section{Results and discussion}

The University (KNUCA) and then the Kyiv Civil Engineering Institute (hereinafter the Kyiv Civil Engineering Institute, KCEI) was established in 1930 on the basis of the Civil Engineering Faculty of the Kyiv Polytechnic Institute and the Faculty of Architecture of the Kyiv Art Institute. ${ }^{3}$ The formation of the Art Institute is associated with the names of outstanding teachers and artists - Mykhailo Boichuk, Vasyl Krychevskyiand, Fedir Krychevskyi, Kazimir Malevich, Oleksandr Murashko, Georgy Narbut and Oleksandr Bohomazov, whose creative experience in the field of graphics, academic painting, sculpture and artistic avant-garde was transferred to the newly created KCEI Faculty of Architecture.

The history of the department is part of the institute's developmental process and its transformation into a university. Also in 1930, a drawing section was created within the Department of Architectural Design, headed by a prominent Ukrainian artist, graphic artist and architect Vasyl H. Krychevskyi.

On this basis, the Department of Drawing and Painting was formed. Later, the department was headed by famous artists and teachers, such as the graphic artist Illarion M. Pleshchynskyi, painter and graphic artist Porfiry D. Zhalko-Tytarenko, as well as artist and candidate of architecture Yurii M. Petrov, author of a new method of organizing the educational process for the artistic training of architects.

A significant stage in the development of the department was the period of its operation under the leadership of the laureate of the State Prize of Ukraine in the field of architecture, Professor Victor V. Chepelyk.

In his scientific and pedagogical activity, Chepelyk organically combined all the components of the educational stages, being a universal teacher in archi-

3 O. Kashchenko, O. Sleptsov, M. Kumeiko (2015) History of the Faculty of Architecture of Kyiv National University of Construction and Architecture. "Architectural Bulletin of KNUCA” Issue 6, pp. 95-110. (original language: О. Кащенко, О. Слєпцов, М. Кумейко (2015) Історія архітектурного факультету Київського національного університету будівництва та архітектури. “Архітектурний вісник КНУБА” Вип. 6, с. 95-110). 
tecture. The focus of his research on the study of Ukrainian national architecture has supplemented the world architectural history with a new concept - Ukrainian architectural Art Nouveau. As the head of the department, Chepelyk developed a method of artistic training of architects in combination with the study and promotion of the works of Opanas H. Slastion, Vasyl Krychevskyi, Dmytro M. Diachenko and other famous people.

Since 1979, the department was headed by Professor Mykhailo F. Yevstifeiev who contributed to the development of methods of graphic images, while the Honored Architect of Ukraine, Doctor of Architecture, artist-watercolorist, Professor Victor V. Savchenko became the head of the department in 1990. Since 1997, the Department of Drawing and Painting has been headed by Doctor of Science in Technical Aesthetics, architect by education, full member of the Ukrainian Academy of Architecture, member of the National Union of Architects of Ukraine, Honored Worker of Education of Ukraine, Professor Oleksandr V. Kashchenko - Dean of the Faculty of Architecture. Along with artistic training of architects, the department introduced the specialization "Fine Arts, Drawing", thus starting to offer master's degree studies. Today it trains first- and second-degree students in the specialization "Artistic and decorative interior decoration". In 2015, a new "Design" specialty was introduced.

Due to an increase in the number of students of new specializations, the Department of Drawing and Painting was structurally reorganized by dividing it into the Department of Fine Arts and Architectural Graphics, and the Department of Design.

Throughout the years, the teaching staff of the Department of Drawing and Painting included talented artists: Oleksii A. Horbenko, Yulia I. Borodai (Dovhan), Volodymyr I. Kolega, Mykola D. Marchenko and others.

A famous figure in the field of art was the artist Yurii I. Khymych. An architect by profession, he created his own style embodied in a series of works of art depicting the architectural monuments of Kyiv, Lviv, Kamianets-Podilskyi and Crimea. His creativity led to a new stage in the modernization of methods of teaching drawing and painting to students-architects.

Innovative techniques in art were introduced into the educational process by the artist Oleksandr Ya. Borovikov - philosopher and psychologist in art. Having perfectly mastered traditional academic artistic means, he successfully experimented in various techniques, creating his own mixed technique of painting and graphics which contributed to the achievement of special originality and expressiveness of his landscapes and still lifes. As a fan and connoisseur of classical music, he often combined drawing with its sound.

The artist creates spiritual and material values, combining social and individual experience, and if the scientific knowledge of the world provides a more 
analytical, generalized reflection, artistic reproduction is full of emotional and sensory content.

Modern methods of teaching art disciplines introduced at the department are based on the use of world experience which shows a tendency to integrate the educational, professional, scientific, creative and social function of university education in diversifying methods of creative learning with an organic transition from retrospective knowledge and skills to productive integral ones. ${ }^{4}$

The binary nature of the spaces of architectural and artistic education, and creative practical activity, their interpenetration, the ratio in the educational process of typical (traditional) and innovative methods encourages the development of new methods of teaching creative disciplines.

The catalyst for the continuous process of becoming an architect-creatorartist is the personality of the artist - as a professional, scientist and teacher. Personalized methods should become an organic component of educational and professional programs of higher architectural and artistic education.

Based on this, the department formulated the basics of the organization of the educational process. The strategy of teaching in architectural and art education at the first stage has an exposing or reproductive character, and involves acquainting students with general concepts, as well as provides basic skills. The second stage is productive, as it involves a purposeful study of objects and techniques of fine arts. The integral third and fourth stage combine general professional information with innovative avant-garde education.

The purpose of training at the first stage of student preparation is to make students learn and revise material acquired at the pre-university stage, its creative theoretical use is the goal of the second stage, while the objective of the third stage is its creative practical application.

The educational content at the first stage is based on empirical knowledge and skills, at the second one - on an academic basis, while at the third one education takes place on a creative and methodological, as well as philosophical and exploratory level. This corresponds to the general concept of artistic training of architects - from the study of the established foundations of the image to the development of the author's creative concepts of artistic creativity.

It is recommended that the educational process should be organized in accordance with the stated strategy, purpose and content of training. It should be frontal at the first stage, including the definition of general creative tasks.

4 Kashchenko Oleksandr (2019) Conceptual principles of architectural and artistic education. "Architectural Bulletin of KNUCA" Issues 17-18, pp. 18-26. (original language: Кащенко Олександр (2019) Концептуальні засади архітектурно-мистецької освіти “Архітектурний вісник КНУБА” Вип. 17-18, сс. 18-26.) 
Studio education is introduced at the second stage and workshop at the third, under the guidance of a recognized master, while individual work prevails at the final stage. It is individual creative work that can bring the most significant results in artistic and compositional developments.

Instructors in such an educational system take on the roles of, respectively: teachers, creators, mentors and research/creative leaders.

The result of such a program is the discipline "Synthesis of Arts and Architecture" in which students combine graphics, painting and sculpture with the development of the architectural environment. Since the specializations "Design" and "Fine Arts, Decorative Arts, Restoration" were introduced, the creative activity of the department has significantly expanded through the preparation and teaching of courses such as decorative and applied arts, applied graphics, decorative painting, etc. The training of master degree students at the department has stimulated the development of research in the theory of art, design, composition, artistic and decorative interior decoration, and folk art.

Understanding the nature and laws of synthesis in plastic arts - architecture, painting, graphics, sculpture - is given a lot of attention in Kharkiv in the process of training and educating architects at the architectural faculty of the Kharkiv National University of Civil Engineering and Architecture (KNUCEA, formerly the Kharkiv Civil Engineering Institute (KCEI)) [four]. ${ }^{5}$ Here, under the guidance of the outstanding artist and doctor of architecture, professor Volodymyr I. Kravets, the Department of Fine and Decorative Arts was created, at which an independent art school was formed.

Its activity is developing in the context of the many problems that architecture and art education in general are facing today. Today, two fundamentally different directions in the prospects for the development of architectural and art education have clearly emerged. One of them is associated with the understanding of architecture as a speculative phenomenon, creating images of the future and corresponding examples of the way of life; the other one

- with an understanding of architecture as a practice that has developed in modern circumstances and will continue to take place for some time to come. At the same time, the system of architectural and artistic education addresses the ideas that are associated with the model of architecture of the near and more distant future. It is not unimportant which model of architecture this

5 Shilo A.V., Aksenov K. A., Litovko S. I., Pyanida Yu. B. (2021) The method of constructive drawing in modern architectural education "Actual research in the modern world" Issue 2 (70), part 1, pp. 39-43.(original language: Шило А.В., Аксенов К.А., Литовко С.И., Пянида Ю.Б. (2021) Метод конструктивного рисования в современном архитектурном образовании "Актуальные научные исследования в современном мире” Вып. 2 (70), ч. 1, сс. 39-43.) 
educational system is built on. Another aspect of this thesis is that the system of architectural and artistic education determines architecture, as well as architectural and artistic synthesis, which in turn determine the requirements for monumental art included in an architectural work.

The perceived symptoms of the current situation regarding the artistic component of architectural education are seen as follows:

- architecture in its modern infrastructural arrangement is ceasing (if it has not already ceased) to be art, more and more clearly turning into engineering, as well as organizational, managerial, economic, sociological, etc. practices, where architecture itself in its traditional sense of "the most significant art" plays a secondary role, losing its professional specificity;

- people not only from outside the profession, but also professionals seem to have forgotten that architectural education is artistic education;

- the consequence is the stagnation of the artistic component of modern architectural education, which manifests itself today in the reduction of artistic training courses and mass loss of professional artistic skills, while in the long term - in the disappearance of the art school and the replacement of the artistic component with photographic recording and computer graphics. As a result, there is a gradual reduction and degradation of plastic thinking as the basis of professional architectural and artistic training.

Traditional architectural and art education was built on the principle of "university" in the exact sense of the word: German Universität which originated from Latin Universitas - totality, community. It was a combination of artistic, humanistic and technical components.

The perceived symptoms of the current situation regarding the traditional professional specifics of architectural and art education are that each of its components claims to be independent and self-sufficient; leadership is established among them "according to the situation". As a rule, the artistic component in these conditions exists "according to the residual principle"; in the professional environment, the idea is that artistic training becomes optional, while in extreme cases you can get by with some special "architectural" hand drawing (what this is, remains unclear even for the supporters of such ideas). The artistic component of modern architectural education is not one of the applied skills of professional training, but a condition for the preservation and development of plastic thinking as a factor in the preservation and development of the professional specificity of architecture. Mastering professional artistic skills is necessary to formulate plastic thinking as the basis of the professional specifics of architecture. For this purpose, it seems necessary to get rid of the myth concerning the existence of some specifically "architectural" hand drawing, to introduce a full cycle of academic art propaedeutics inherent in 
art universities into the practice of modern architectural and art education, to study and master all (or at least the main) historically formed (canonical and non-canonical) forms of plastic thinking and the corresponding conventions of various systems of (traditional and avant-garde) plastic language as means of expressing certain historically formed contents, as well as to appropriately rebuild the humanitarian and technical components of architectural and artistic education (for example, along with an academic course in art history, update a course in "practical history of art" within which it is possible to create stylizations on given topics, accomplish them with the help of authentic constructive means, etc.).

In the conditions of a systemic crisis of architectural and artistic education, the Department of Fine and Decorative Arts (FDA) of KNUCEA managed both to preserve the basic foundations of traditional academic propaedeutics and to master various aspects of avant-garde forms of plastic thinking. Today, it is vital to preserve this component as the most important resource for the existence of the Kharkiv architectural and art school.

A feature of the reproduction of artistic tradition is the significant role of the handicraft component in transferring teachers' experience to students "from hand to hand". One of the founders of the FDA department art school was Professor Vitalii N. Kulikov. He was a student of Hryhorii A. Bondarenko who studied with Konstantin S. Petrov-Vodkin, a direct student of Valentin A. Serov who studied under Ilya Ye. Repin and Pavel P. Chystiakov. Repin also studied with Chystiakov, a key figure in art education in the 19th century.

Thus, Kulikov was directly exposed to this artistic ideology, tested it using his own creativity and implemented it in his teaching practice as a method of constructive drawing. The method is based on three main components.

The first one assumes a dual understanding of a sheet. On the one hand, it is conceived as a projection plane which is solved compositionally, while on the other hand - as a space which actualizes the theme of the construction of the depicted world which must be embodied in a convincing and competent way.

The expressiveness of the construction of a structure actualizes the second component of the method - a combination of projections.

Finally, the third idea is that the image is understood as a way of processing the pictorial plane. In it, deformations formed as a result of combining projections are either revealed, which is characteristic of the latest trends, or masked, which leads to the traditional understanding of the artistic form.

Here, another important component of art education is actualized, which, as it seems today, needs to be paid attention to, as it turns out to be somewhat obscured by all sorts of now fashionable searches for ways of self-expression, form-creative experimentation, etc. This is the artistic education of a profes- 
sional [8], particularly of their artistic taste. The most important thing here is the experience of communication between students and already established masters while working in the mode of master classes. Therefore, all the instructors at the department (16 people today) work not only as teachers, but also practicing artists.

In the course of master classes, the technique of formulating plastic tasks is mastered through working "in the key" of one of the selected masters. Such work is fundamentally opposed to copying. Copying is usually a technical procedure. Working "in the key" of a master does not involve formal repetition of someone else's solutions, but comprehension of the technique of formulating and solving plastic problems with reference to one's own material, i.e. it is not technical, but intellectual and creative work.

The peculiarity of art education lies in the combination of craft reproduction skills, direct creation, as well as theoretical comprehension and reflection. If craft skills are simply reproduced, a technique is mastered, but thinking is not formed. You can learn to master a technique very well, but mastering the technique of a Master does not make the disciple a Master.

At the same time, reproducing a technique by applying manual work skills is a necessary element, without which the formulation of plastic thinking is impossible.

Therefore, it is absolutely necessary to imitate established masters at the initial stages of artistic development. Through imitation, cultural practice is mastered and one enters the profession.

One method of artistic education and upbringing is a system of creative workshops at the Department of Fine and Decorative Arts, within whose framework students work independently, as well as individually with their teachers, not only via consultation, but also through master classes. These workshops are gradually becoming the dominant form of artistic training today. They are now conducted by recognized masters with great creative experience, for example:

- Honored Architect of Ukraine, corresponding member of the Academy of Architecture of Ukraine, Doctor of Architecture, Professor Volodymyr Iosyfovych Kravets who studied at the Kharkov Art Institute with an outstanding artist, classic of the Ukrainian avant-garde, Borys V. Kosarev. He successfully worked as a set designer, illustrator and master of monumental art. In recent decades, Volodymyr Iosyfovych has been working on easel watercolor sheets, mainly in the genre of architectural landscape and portraiture. As a scientist, Volodymyr Iosyfovych created the theory of coloristic harmony and an important scientific school that develops various aspects of its application in architectural development; ${ }^{6}$

- Yevhenii Ivanovych Svetlychnyi who graduated from the Kyiv Art Institute where he studied under the USSR artists T. N. Yablonska and Victor 
H. Puzyrkov. Having received strong traditional artistic training, he has been following his creative path as a non-conformist artist involved in modernism. Together with Volodymyr N. Shaposhnikov, he has implemented many monumental projects, culminating in their joint exhibition at the National Art Museum of Ukraine in 2020;

- Doctor of Arts, Professor Oleksandr Vsevolodovych Shylo who studied at the architectural faculty of KCEI under professors Vitalii N. Kulikov and Volodymyr I. Kravets. His creative experience is associated with the development of small forms in painting and graphics. He has established himself as a master of landscape, portrait and still life, and presented his works at more than a hundred exhibitions and in the collections of a number of museums;

- Volodymyr Serhiovych Kochmar who studied with prominent representatives of the "severe style"- at the sculpture faculty of the Kharkov Institute of Art and Industry under Petro P. Yurchenko and at a private studio with Vitalii I. Lenchyn. He works a lot and productively in monumental and easel sculpture, as well as in easel graphics. A long-term participant and laureate of numerous international symposia on sculpture. His works adorn the cities of more than ten countries in Europe, Asia and America.

Artistic training carried out by the department of FDA gives the graduates of the architectural faculty of KNUCEA additional resources for further - already postgraduate - creative self-determination. Its capabilities are determined by today's problems of the development of artistic culture.

Along with large universities located in the two largest cities of Ukraine - Kyiv and Kharkiv, it is advisable to consider how the artistic training of architecture students at the relatively small National University "Yuri Kondratyuk Poltava Polytechnic" (called Poltava Civil Engineering Institute in the Soviet period), located in the regional centre - Poltava, was organized and changed over time. The first enrollment in the architectural specialization took place in 1966 and the first graduation - in 1971, respectively, while in 1972 the Faculty of Architecture was established. From the beginning, a lot of attention was paid to the artistic training of future architects and it developed together with the school of architecture. Already in the 1980s, well-known artists joined the artistic training. At that time, many students with artistic abilities entered the architectural specialization, attracted by the opportunity to receive quality artistic training, but after graduation worked not as architects, but artists

6 Shilo Aleksandr (2008) Vladimir Kravets. Sketch for a portrait against the background of the exhibition."Traditions and innovations in all architectural and artistic education" Issue 4-5-6, pp. 110-114. (original language: Шило Александр (2008) Владимир Кравец. Эскиз к портрету на фоне выставки. “Традиції і новації у вищій архітектурнохудожній освіті” Вип. 4-5-6, сc. 110-114.) 
(particularly Ruslana Anichina, Olena Odarych and Victoriia Gurzhii). This problem was solved when a new specialization "Decorative and Applied Arts" was introduced in 1995 and, accordingly, a separate department of fine arts was created. Introducing this specialization in Poltava helped create conditions for the preservation and development of the cultural and artistic heritage of the ceramics of the Poltava region (Opishnia ceramics). A few years later, the specialization "Fine Arts" was added. Of course, the emergence of new specializations has led to changes in the artistic training of future architects. It has become more specific, focused on the needs of the architectural field and, of course, simpler and less extensive than for students of art specializations.

The situation changed quite a lot in 2014-2015, due to three main factors. First of all, there was a significant reduction in the number of applicants caused by the so-called "demographic pit" of the 1990s, accompanied by a deteriorating economic situation when far fewer people could afford to study at a university. Secondly, the military aggression of the Russian Federation led to the loss of control over part of the Ukrainian territory, resulting in a collapse of the economy and redistribution of budget funds for defense needs. Thirdly, the "Law of Ukraine On Higher Education" was adopted. It is stated in paragraph 2 of Article 56 of the law that the maximum training load per representative of research and teaching staff is decreased 1.5 times - from 900 to 600 hours per year. The intention of the law drafters was to free up teachers' time for scientific work in the conditions of the economic crisis, which resulted in a sharp decrease (1.5 times or even higher) in the number of classes. In addition, the length of first-degree (bachelor's) studies was reduced from 4.5 to 4 years (it is when the artistic training of architecture students takes place). In such conditions, the number of drawing, painting and sculpture classes naturally decreased. Since 2017, the number of foreign students receiving education in English has grown significantly and now they account for $40 \%$ of all bachelor's degree students. This has affected the curriculum content: foreign graduates of the National University "Yuri Kondratyuk Poltava Polytechnic" have mostly been employed in their home countries (Turkey, the Middle East, North and Central Africa) and the level of their acquired practical skills should not be inferior to that of local university graduates. An average lower level of graphic training of foreign applicants, compared to Ukrainian students, should also be noted here.

All these factors have contributed to the fact that the artistic training of students majoring in the architectural specialization "Architecture and Urban Planning" (191) has become even more different from the training of students majoring in "Fine Arts, Decorative Arts and Restoration" (023). In the training of future architects, the importance and scope of the study of computer 


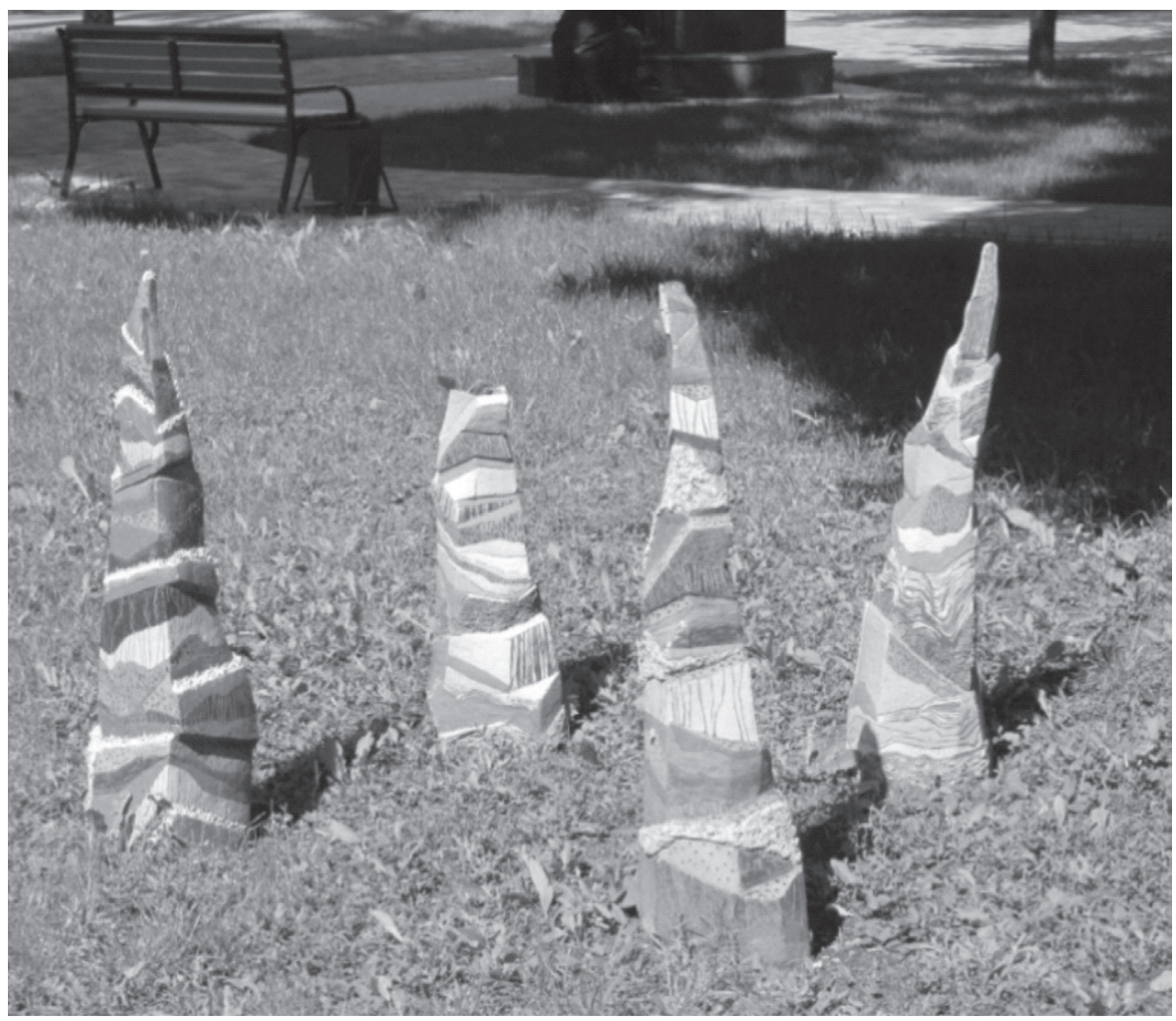

1. The use of graduation works of art specializations students in landscape organization of the National University "Yuri Kondratyuk Poltava Polytechnic" area. Photo by A. Dmytrenko, 2021.

graphics, 3D modeling and computer visualization has increased. At the same time, the staff of the Department of Fine Arts, now headed by Associate Professor Tetiana M. Zinenko, Ph.D. (Art History), have managed to maintain the character of the Poltava school by continuing the traditions of artistic ceramics and working in close cooperation with architects, even when educational specializations were unified in 2015, according to a resolution of the Cabinet of Ministers of Ukraine (three architectural specializations were merged into one and so were several art specializations). For example, students of the architectural specialization are actively involved in the development of landscaping projects of the university plot where graduation works of art specializations students are used as small architectural forms (Fig. 1). 


\section{Between practice and theory. The specificity of art history teaching at the University of Kódź}

Educational processes at the academic level are traditionally embedded between the fields of theory and practice. ${ }^{7}$ They most obviously occur in the sciences, but also in the humanities. Such connections, as well as the resulting benefits and challenges are also found in the area of art-related sciences. Undoubtedly, the scientific, teaching and artistic activity of Prof. G. Sztabiński was inextricably linked with these issues. It was also influenced by the specific nature of Łódź.

Ties between theory and practice are inherently inscribed in research on the history of art conducted at the University of Łódź. It can be concluded that this is a characteristic element of the city of Łódź, resulting from its history and specificity. There are at least three important entities related to the practice and theory of art in Lódź $^{8}$ They combine the interests of museologists, practicing artists, art critics and classical art historians. For chronological reasons, the Łódź Art Museum should be mentioned first. The origins of this institution, established before World War II, are linked to avant-garde postulates of artists belonging to the a.r. group headed by Władysław Strzemiński. From the very beginning, the collection included examples of the most important trends of avant-garde art, being a kind of a phenomenon on a world scale. The institution that developed after the war continued these traditions, significantly contributing to research efforts related to contemporary artistic phenomena. The second entity that has contributed to the specific image of research on art in Łódź is the Strzemiński Academy of Fine Arts. The establishment of the Academy in 1945 was a culmination of many years of efforts made by the local artistic community. Thus, in 1945, the image was completed with academic history of art. It was a time of post-war reconstruction and reorganization of Polish higher education formed in the new political and territorial realities. New scientific institutions brought together researchers from various centres, who had to redefine their position and place of work. This post-war mobility fostered original change and intellectual experimentation.

7 Per Johansen, The Interdepedence of Theory and Practice in Art Education, "Art Education", vol. 36 (1983), no. 1, pp. 20-22; Harold Pearse, Beyond Paradigms: Art Education Theory and Practice in a Postparadigmatic World, "Studies in Art Education. A Journal of Iusses and Research", vol. 33 (1992), pp. 244-252.

8 W. Nowakowska, W strone nowoczesności - historia sztuki na Uniwersytecie Łódzkim, [in:] Dzieje historii sztuki w Polsce. Ksztaltowanie się instytucji naukowych w XIX i XX wieku, ed. A.S. Labuda, Poznańskie Towarzystwo Przyjaciół Nauk, Poznań 1996; P. Gryglewski, The Department of Art History at the University of Łódź and the research into the avant-garde movement, „Art Inquiry. Recherches sur les arts”, 19 (2017), pp. 13-16. 
In the spring of 1945, professors Wacław Husarski and Mieczysław Wallis started to organize courses at the University of Łódź. They were outstanding individuals combining very different interests and experiences. Professor $\mathrm{Hu}-$ sarski had the experience of an art historian, painter and art critic. Professor Wallis, a graduate of the universities in Warsaw and Heidelberg, also had various interests. He combined those of an art historian and philosopher with the practice of an art critic and theorist. These diverse and complementary experiences of the researchers of artistic phenomena influenced the specific and innovative character of Łódź art history already at the beginning. Freed from the constraints of previous scientific traditions, the team could fully open to new and current phenomena. This became natural in an environment where the artistic tradition of the pre-war avant-garde was alive. Thus, at the very beginning of Łódź art history education, there was an unusual connection between traditional art history, aesthetics, criticism and artistic theory, interestingly combined in some cases with artistic practice. The link between history and modernity, as well as the introduction of aesthetic interests and criticism into the academic art history institution from the very beginning, undoubtedly had a pioneering and modern character.

The combination of art theory and aesthetics with the classical art historian's research field was also maintained later, after re-establishing the art history major at the University of Kódź in 1992. This attitude was closest to the academic activity of Prof. Grzegorz Sztabiński who successfully combined deep aesthetic and theoretical reflections with the experience of an artist in practice. In his long academic career, he tried to confront the attitudes of an artist-researcher and an artist-philosopher. Professor Grzegorz Sztabiński belonged to the group of relatively few conscious art researchers who formulate their conclusions with the simultaneous use of practical experience. This two-sided view was certainly a great advantage and an opportunity. There are several levels of practical engagement in the process of academic art history teaching. Obviously, live contact with a piece of art, whether architectural or plastic, with its complex context, is of paramount importance. The necessity to value a piece of art, be it from the point of view of conservation or the challenges of art criticism, also requires practice. Skills in this area are developed over time, as a result of a systematic confrontation between theory and practice. Respecting these attitudes, Prof. Grzegorz Sztabiński introduced one more element into the teaching process, namely the experience of a practicing artist, an artist open to theoretical reflection. It is certainly difficult to overestimate such an attitude which has gained particular significance, especially in relation to research on the newest art in its various forms. The interdisciplinary profile of Łódź art history education, which can be boldly described as specific for this city, is continued by a generation of younger researchers. 


\section{Conclusions}

The analysis of professional training for art students and fine arts teaching for students of architecture at universities in Ukraine over several decades has shown a gradual increase in contradictions between the classic teaching program and the needs of today. The former focuses on making students deeply acquaintanced with recognized works of art, imitation of traditional performance techniques and continuity in teaching programs, while the latter require other responses to the demands of society, especially young people. Compared to previous generations, modern youth are less interested in classical art, instead seeking other, freer forms of creative self-expression. The issue of artistic theory and practice also emerges in the case of teaching history of art at the University of Łódź.

Art is an abstract concept that acts as a form of social consciousness and a specific type of activity that is designed to reflect reality in concrete emotional images, in accordance with established aesthetic ideals, while it also denotes masterful perfection in any field. Art is becoming an important philosophical category because it is a specific form of knowledge and reflection of the world around us, and it is also becoming an important component of the spiritual culture of mankind, so it is often called a branch of spiritual production.

Accelerating changes in artistic and architectural trends are due to the increasing globalization, internationalization of society and development of digital technologies, which have radically changed the meaning of the concept of a "work of art". It now includes what was not considered to have the rank of art. If in the past centuries art was primarily a means of aestheticization, then, since the first decades of the twentieth century, its social context has been changing: starting from a method of cultural and aesthetic education, art is becoming a kind of a message, as well as transmission of certain information and context from the artist to the viewer, even in the form of trash, shock or outrage. The awareness of such dependencies is also an important element in the education of art historians.

Historical theories of art claim a direct relationship between the process of recognizing a phenomenon as art and existing works of art acting as a standard or template. This dependence on the standard leads to the question whether such a comparison with what exists and is recognized in society is necessary, because it essentially means the following: any phenomenon is art if it is historically related to previous works and earlier forms of art.

The aesthetic preferences of society are changing due to, among other things, the fact that certain social groups (e.g. youth) reject traditional art. This leads to a situation where works that were previously not considered art - e.g. street art, various performances, etc. are given the rank of art and the status of works of art. ${ }^{9}$ 
At the same time, the change in the content of the term "art" has been caused by the inability of traditional cultural institutions to meet the cultural and artistic needs of today, due to their restriction of free creative self-expression. That is why there is a need to consider the changes in public perception of art. This also pertains to art education and its modernization, making students acquainted with modern art trends and ensuring their participation in street festivals which are becoming more and more widespread, and are designed to legalize cultural artistic phenomena that did not previously belong to the categories of art. Such an example is the graffiti festival "COLORIT" that was held on May 15-16, 2021 in Dnipro, organized by the AKS Charitable Foundation in cooperation with Bartolomeo Best River Resort (Fig. 2). The festival was dedicated to the Europe Day in Ukraine, so its theme was "The Cities and Countries of Europe". It was attended by several dozen of the most famous mural artists using the technique of aerosol painting.

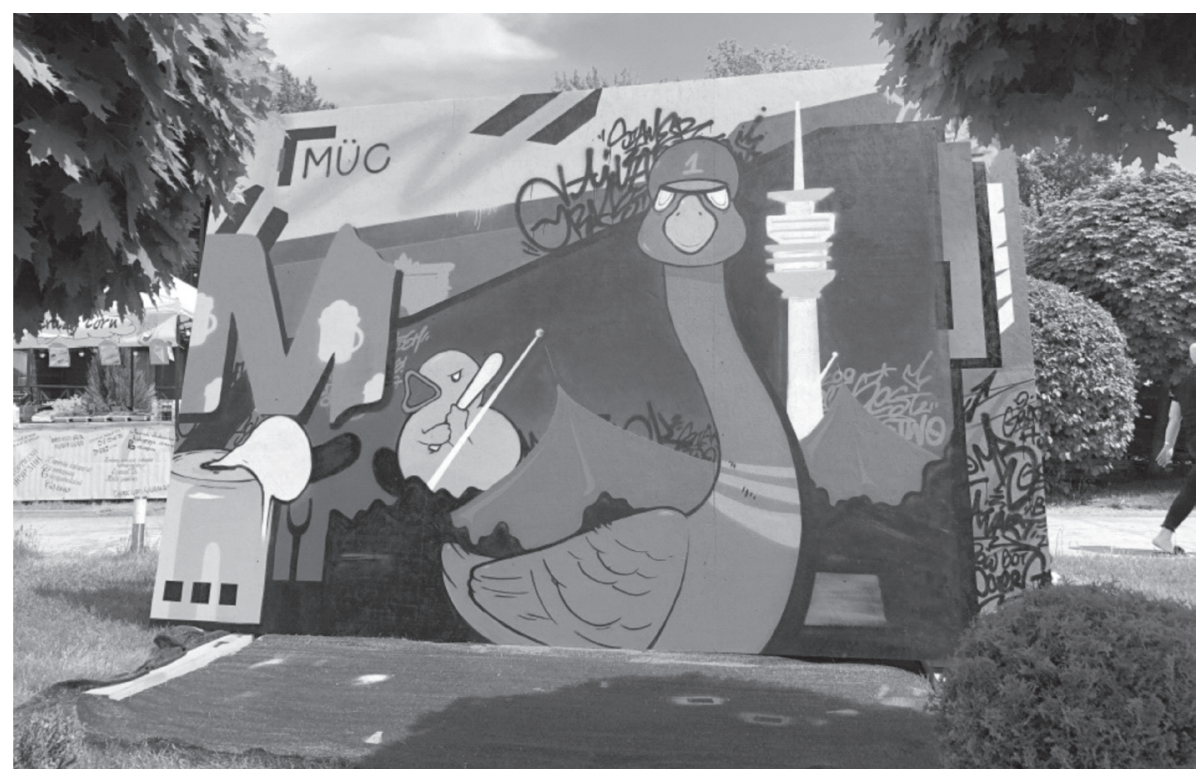

2. Painting "Munich" at the graffiti festival "COLORIT". Author: O. Ivashko. Photo by O. Ivashko, 2021

9 O. Shylo, O. Ivashko (2016) Monumental art and street art in the modern urban space. "Scientific Bulletin of Construction" No. 2 (84), pp. 74-78. (original language: О. Шило, О. Івашко (2016) Монументальне мистецтво і стріт-арт в сучасному міському nросторі. “Науковий вісник будівництва” № 2 (84), сс. 74-78.) 


\section{BIBLIOGRAPHY:}

Kashchenko Oleksandr, Sleptsov Oleh, Kumeiko Marharyta (2015) History of the Faculty of Architecture of Kyiv National University of Construction and Architecture. "Architectural Bulletin of KNUCA” Issue 6, pp. 95-110. (original language: Кащенко Олександр, Слєпцов Олег, Кумейко Маргарита (2015) Історія архітектурного факультету Київського національного університету будівництва та архітектури. “Архітектурний вісник КНУБА” Вип. 6, сс. 95-110).

Kashchenko Oleksandr (2019) Conceptual principles of architectural and artistic education. "Architectural Bulletin of KNUCA” Issues 17-18, pp. 18-26. (original language: Кащенко Олександр (2019) Конщептуальні засади архітектурно-мистецької освіти "Архітектурний вісник КНУБА” Вип. 17-18, сс. 18-26.)

Shilo Aleksandr (2008) Vladimir Kravets. Sketch for a portrait against the background of the exhibition. "Traditions and innovations in all architectural and artistic education" Issue 4-5-6, pp. 110-114. (original language: ШилоАлександр (2008) ВладимирКравец. Эскиз к портрету на фоне выставки. “Традиції і новації у вищій архітектурно-художній освіті” Вип. 4-5-6, cc. 110-114.)

Shilo A. V., Aksenov K.A., Litovko S.I., Pyanida Yu.B. (2021) The method of constructive drawing in modern architectural education "Actual research in the modern world" Issue 2 (70), part 1, pp. 39 43. (original language: Шило А.В., Аксенов К.А., Литовко С.И., Пянида Ю.Б. (2021) Метод конструктивного рисования в современном архитектурном образовании "Актуальные научные исследования в современном мире” Вып. 2 (70), ч. 1, сс. 39-43.)

Shylo Oleksandr, Ivashko Oleksandr (2016) Monumental art and street art in the modern urban space. "Scientific Bulletin of Construction" No. 2 (84), pp. 74-78. (original language: Шило Олександр, Івашко Олександр (2016) Монументальне мистецтво і стріт-арт 8 сучасному міському просторі. “Науковий вісник будівництва” № 2 (84), сс. 74-78.)

Sztabiński Grzegorz (2019) Why Do We Need the Term "Art"? "Art Inquiry. References sur les arts”, vol. XXI (XXX), pp. 19-35.

Sztabińska Paulina (2014) Contemporary artist and the notion of center and periphery. "Art Inquiry. Recherches sur les arts" vol. XVI, pp. 45-56.

Sztabińska Paulina (2016) Performance art, performativity and the issue of neomodernism. "Art Inquiry. Recherches sur les arts” vol. XVIII (XXVII), pp. 161-176.

Sztabińska Paulina (2017) Digital performance and avant-garde artistic distinctions. "Art Inquiry. Recherches sur les arts” vol. XIX (XXVIII), pp. 257-272.

Sztabińska-Kałowska Paulina (2018) Performance and Participatory Art. "Art Inquiry. Recherches sur lest arts” vol. XX (XXIX), pp. 185-201.

Sztabińska-Kałowska Paulina (2019) How Does a Performance Affect the Understanding of 'Art'?

“Art Inquiry. Recherches sur les arts” vol. XXI (XXX), pp. 111-128. 


\section{MIĘDZY PRAKTYKA A TEORIA. UWAGI O EDUKACJI ARTY- STYCZNEJ I Z ZAKRESU HISTORII SZTUKI W POLSCE I NA UKRAINIE (streszczenie)}

Przemiany zachodzące w obszarze praktyki artystycznej dokonują się równolegle z przekształceniami w obszarze społecznym. Plastyczna i architektoniczna aktywność współistnieje z refleksją teoretyczną z zakresu sztuki. Zmiany tego rodzaju przekładają się również na założenia jakimi kierują się badania z obszarów historii sztuki. Współczesna sztuka charakteryzuje się dynamicznymi przemianami i przewartościowaniami, w których przeplata się praktyka i teoria. Charakter tych zjawisk jest wyzwaniem również na poziomie edukacji akademickiej podejmującej tematykę sztuki, architektury czy historii sztuki. Specyfika analizowanych zjawisk wpływa na konieczność łączenia w tym procesie wiedzy teoretycznej z szeroko pojmowaną praktyką.Estetyczne założenia sztuki współczesnej są szeroko wykorzystywane w procesie edukacji artystycznej. Przykładem tego mogą być działania podejmowane w ramach Kijowskiego Narodowego Uniwersytetu Budownictwa i Architektury (KNUCA, Kyiv Civil Engineering Institute). Kolejni wykładowcy tej uczelni konsekwentnie w procesie edukacyjnym łączyli założenia teoretyczne z praktyką twórczą. Założenia te znalazły zastosowanie w projektowaniu architektonicznym, wykorzystującym elementy plastyczne. Związki teorii i praktyki są immanentnie wpisane również w dzieje historii sztuki na Uniwersytecie Łódzkim. Duży wpływ na to miała specyfika łódzkiego ośrodka, w którym bardzo wcześnie, już przed II wojną światową, pojawiło się zainteresowanie sztuka nowoczesna, na poziomie teorii, praktyki i muzealnictwa. Taka postawa była też bliska aktywności akademickiej prof. G. Sztabińskiego, który pogłębione refleksje estetyczno-teoretyczne w udany sposób łączy z doświadczeniami artysty praktyka.

Słowa kluczowe: teoria sztuki, edukacja artystyczna, metodologia nauczania, historia sztuki, Łódź, Kijów

Piotr Gryglewski, PhD in Humanities (History of Art), Professor at the University of Łódź. Art historian associated with the Department of Art History, University of Łódź, since 1992. Specializing in the works of art of the Renaissance and Baroque periods with a special focus on architecture, he deals with the problems of the basics of art, as well as historical art content and elements promoted in contemporary art. Editor of the series "Sztuka Polski Środkowej" and the semi-annual TECHNE / TEXNH.

1. Vetusta monumenta. Szlacheckie mauzoleum od pot. XV w. do XVII w., Łódź 2002.

2. P. Gryglewski, R. Wróbel, A. Ucińska, Łódzkie budynki 1945-1970, Łódź 2009.

3. De Sacra Antiquitate. Odwołania do przeszłości w polskiej architekturze sakralnej XVI wieku, Warszawa 2012.

4. Z. Bania, A. Bender, P. Gryglewski, J. Talbierska, Sztuka polska. Wczesny i dojrzaty barok (XVII wiek), Warszawa 2013.

5. Arquitectura de Eódź después de la Segunda Guerra Mundial (1945-2010). Confrontación o convivencia. Las nuevas inversiones en el patrimonio arquitectónico de la ciudad, [w:] El diseńo para la calidad de vida en el espacio habitable, Mexico 2015, pp. 83-96. 
Denys Chernyshev, Doctor of Technical Sciences (2019), Professor (2019). In 2008, he was the chief design engineer in a design organization. In 2014, he was Vice-Rector for Education, Training and Production Work. Since 2015, he has been the first Vice-Rector of the Kyiv National University of Construction and Architecture. Member of the Council of Vice-Rectors under the Ministry of Educationand Science of Ukraine. Author of more than 70 scientific publications. His scientific interests and fields of scientific activity include the organization of construction, architecture and contemporary art.

1. Chernyshev Denys, Methodology, analytical tools and practice of organizing the biosphere friendly construction, Kyiv 2017.

2. Chernyshev Denys, Update the structure and content of the leading resource-time indicators of construction projects in the models construction organization, [in:] Prospects of World Science - 2017: XIII International Scientific and Practical Conference July 30 - August 7, 2017: con ference materials. Sheffield: Science and Education LTD 2017. Volume 4. Pp. 24-26.

3. Chernyshev Denys, New trends in organization and design of city space in the conditions of the urban understanding: problems and development perspectives, [in:] Conduct of Modern Science - 2017: XIII International Scientific and Practical Conference, November 30 - December 07, 2017: conference materials. Sheffield: Science and Education LTD 2017, Volume 13. Pp. 77-78.

Oleksandr Kashchenko, Doctor of Technical Science, Professor, Dean of the Architectural Faculty of the Kyiv National University of Construction and Architecture.

1. Kashchenko Oleksandr, Kovalska Gelena, Gnatiuk Lilia (2020) Revitalization of the urban environment and contemporary trends of its humanization via the means of art. "Wiadomości Konserwatorskie - Journal of Heritage Conservation” No. 61, pp. 31-34.

2. Polubok A. P., Kashchenko A.V. (2020) Methods for correcting the scale proportions of sculpture and architectural space. "Colloquium-journal" No. 25 (77), pp. 4-7. (original lan guage: Полубок А. П., Кащенко А. В. (2020) Методы корректи ровкимасштабнойсо размерностискульптурыи архитектурного пространства. // "Colloquium-journal" № 25 (77), cc. 4-7.)

3. Kashchenko O. V. (2019) Artistic modeling in biodesign. "Art \& Design” Issue 3, pp. 58-63. (original language: Кащенко О. В. (2019) Художньо-образнемоделюваннявбіодизайні. “Art\&Design” Вип. 3, сс. 58-63.)

4. Kashchenko O. V. (2019) Equivalent modeling of natural analogies in the formulation of an architectural and subject center. "Ethnic design in the context of the Ukrainian national revival and European integration” Book 3, pp. 181-185. (original language: Кащенко О. В. (2019) Рівні моделювання природних аналогів при формуванні архітектурнопредметного середовища. "Етнодизайн в контексті українського національного відродження та європейської інтеграції” Кн. 3, сс. 181-185.)

Alexander Shilo, Sc.D. in Art History, Professor, anartist. Department of Fine and Decorative Arts, Kharkiv National University of Civil Engineering and Architecture, Kharkiv, Ukraine. Research interests - problems of history and theory of fine arts, architecture and design, research in the field of methodology of artistic activity, study of canonical and non-canonical art systems, personalities of Russian and Ukrainian art of the 19th and 20th centuries.

1. Shilo A. V. Repin's Riddles, Kharkiv 2004. (original language: Шило А. В. Загадки Репина, Харьков 2004.) 
2. Shilo A. V. Canon and plastic thinking in the art of the Middle Ages, Kharkiv 2006. (original language: Шило А. В. Канон и пластическое мышление в искусстве средних веков, Харьков 2006.)

3. Shilo A. V., Panova M. V. To the methodology of a portrait, Kharkiv 2007. (original language: Шило А. В., Панова М. К методологии портрета, Харьков 2007.)

Yulia Ivashko, Doctor of Science (Architecture) (2013), Professor (2014), Doctor habilitatus, nostrificated (2018). Author of over 550 scientific publications and monographs. Scientific interests and fields of scientific activity: folk architecture of different countries of the world, architecture and the art of historicism - eclecticism and Art Nouveau, Islamic architecture and art, the architecture and art of China, restoration of works of art.

1. Ivashko, Yu., Houses of Kyiv with gothic elements (study of history and architecture), editor-in-chief M. Dyomin, Kyiv 2004.

2. Ivashko, Yu. V., Art Nouveau style in architecture of Kyiv, editor-in-chief M. Dyomin), Kyiv, Gopak, 2007.

3. Ivashko, Yu., Li Shuang. Art Nouveau of Western Europe, Ukraine and China: the ways of transformation and implementation, editor-in-chief M. Dyomin, Kyiv 2015.

4. Orlenko, M., Ivashko, Yu., Li Shuang, Reincarnation of the Northern National Romanticism: investigation and experience in the restoration of objects, editor-in-chief M. Dyomin, Kyiv 2016.

5. Dyomin M., Ivashko Yu., Rezga K. Mosques of Algeria:Architectural and Urban Aspects, Kyiv 2019.

Andrii Dmytrenko, PhD, Associate Professor, the National University "Yuri Kondratyuk Poltava Polytechnic". Author of more than 170 scientific publications. Scientific interests and fields of scientific activity: history of architecture, regional peculiarities of national architecture, architecture of buildings and structures, demographic aspects of spatial planning.

1. Dyomin M., Chernyshev D., Dmytrenko A., Kuzmenko T., Chang P. (2020) A breakthrough in landscape design: from traditional garden of ancient despots to the avant-garde "garden of Cubism" "Landscape Architecture and Art" Vol. 16, No. 16, pp. 70-79.

2. Gryglewski Piotr, Ivashko Yulia, Chernyshev Denys, Chang Peng, Dmytrenko Andrii (2020) Art as a Message Realized Through Various Means of Artistic Expression. "Art Inquiry. Recherches sur les arts” vol. XXII, pp. 57-88.

3. Ivashko Y., Dmytrenko, A., Paprzyca, K., Krupa, M., Kozłowski, T. 2020 Problems of Historical Cities Heritage Preservation: Chernihiv Art Nouveau Buildings. "International Journal of Conservation Science”, 11 (4), pp. 953-964.

Ivashko Oleksandr - Ph.D, an architect and an artist. Scientific interests and fields of scientific activity: street art, contemporary art, art clusters.

1. Ivashko, O. D., Orlenko M. I. Art-Clusters as a New Type of Buildings: the Specificity of the Spatial Solution and the Features of Restoration during the Redevelopment Process (The Experience of Poland). / Środowisko Mieszkaniowe (Housing environment), Kraków, 2017. No. 21. pp. 109-115.

2. Iwaszko O. Społeczna Przyroda Nowych Artystycznych Kierunków w Miejskim Środowisku, "Przestrzeń/Urbanistyka/Architektura" 2/2018, pp. 167-176.

3. Ivashko, O., Perehuda, Ye. Street art as a factor of cultural development and an element of symbolic politics in post-revolutionary Ukraine. Stosunki międzykulturowe. Tom 1. Strategie bezpieczeństwa i komunikacji we wspótczesnym świecie, Zielona Góra, 2016, pp. 155-174. 
4. Ivashko O. Możliwości użycia sztuki ulicznej we wspótczesnym dostosowaniu zamków i twierdz. Current issues in research, conservation and restoration of historic fortifications, Chełm-Lviv, 2016, pp. 86-90.

5. Dyomin Mykola, Ivashko Oleksandr. Street Art as a new Phenomenon of Art - a Means of Centrification of the Urban Environment, "Art Inquiry. References sur les arts", volume XXI (XXX), pp. 129-148. 